\title{
EXECUÇÃO PENAL PROVISÓRIA AUTORIZADA PELO STF: AMPLIAÇÃO DE ESTADO DE EXCEÇÃO NO BRASIL
}

\author{
José Vagner de Farias ${ }^{13}$
}

Recebido em: $31 / 08 / 2018$

Aprovado em: 26/02/2019

\begin{abstract}
RESUMO
O presente estudo tem como objeto a análise das decisões pelo STF do Habeas Corpus 126.292 SP e Ações Declaratórias de Constitucionalidade $n^{\circ} 43$ e 44, as quais provocaram intenso debate jurídico, à luz da teoria do estado de exceção. Tais decisões possibilitaram a execução provisória de pena após condenação de segundo grau pelo Poder Judiciário, mesmo pendente recurso a tribunal superior, sem necessidade de apurar possível prisão cautelar, já prevista no ordenamento. Questiona-se se tal decisão não viola expressamente a norma de presunção de inocência prevista no artigo $5^{\circ}$, inciso LVII da Constituição Federal de 1988. Busca-se verificar se a decisão guarda relação com o contexto político e econômico que o país passou a viver após as manifestações de junho de 2013. Em seguida, é feita uma abordagem legal e doutrinária das decisões dos ministros sobre as decisões mencionadas. Analisa-se os pensamentos de Carl Schimitt, Walter Benjamin e Giorgio Agambem sobre estado de exceção. É feita uma abordagem, trazendo um paralelo das principais idéias destes pensadores com a questão da prisão penal automática após condenação de segundo grau. A pesquisa foi realizada por meio de estudo bibliográfico. Trata-se de decisão polêmica que mudou entendimento pacificado pelo próprio STF em 2009.
\end{abstract}

Palavras-chave: Estado de exceção. Presunção de inocência. Direitos Fundamentais.

\section{INTRODUÇÃO}

Este trabalho terá como objeto a análise inicial três decisões recentes pelo Supremo Tribunal Federal (STF) que possibilitaram um novo entendimento de grande repercussão social prática do Direito Penal para a sociedade. Tratam-se dos julgamentos ocorridos no

\footnotetext{
${ }^{13}$ Doutorando em Direito Constitucional pela Universidade de Fortaleza - UNIFOR. Mestre em Direito Constitucional pela UNIFOR. Especialista em Direito e Processo de Família e Sucessões pela UNIFOR. Defensor Público do Estado do Ceará.
} 
Habeas Corpus 126.292 e Ações Declaratórias de Constitucionalidade 43 e 44, que proporcionaram debate jurídico na instituição que possui a última palavra em matéria de controle de constitucionalidade. O tema teve de ser enfrentado duas vezes no mesmo ano de 2016.

Por maioria de seus membros, por 6 votos a 5, o plenário mais alta corte do país, que segundo a Constituição Federal, deve ser o guardião da mesma, fixou-se entendimento de que o Art. 283 do Código de Processo Penal (CPP) não impede a execução de pena automática após condenação segunda instância, sem prejuízo de possíveis recursos na legislação. A decisão foi alvo de duras críticas por juristas vinculados às teorias garantistas e, ao mesmo tempo, de aplausos por grande parte da mídia, do Poder Judiciário e Ministério Público.

Torna-se imprescindível buscar compreender as razões de decisão para além dos autos processuais. Defende-se que a referida decisão serve como exemplo em um contexto de estado de exceção, conforme o pensamento de Giorgio Agambem. Este pensador italiano traz um pensamento relevante para a compreensão dessa mudança de interpretação, que foi confirmada em 05 de outubro de 2016, exatamente 28 (vinte e oito) anos após a promulgação da "Constituição Cidadã".

Em sua obra "Estado de Exceção", que será devidamente abordada posteriormente, tem-se uma série de reflexões filosóficas que podem ajudar compreender o caráter de mudança tal radical tomada pela mais alta corte do país, sem se olvidar do contexto político e econômico que aqui se defende após as manifestações de junho de 2013.

Também se faz necessário um paralelo sobre as próprias concepções do que vem o "Estado de Exceção" na leitura histórica da expressão, que nasce com Schmidt, passa por Benjamim e chega até Agamben.

Inicialmente é feita uma abordagem sobre o princípio da presunção de inocência. Em seguida, analisa-se o contexto político por que passa o Poder Judiciário, em especial no que concerne ao recente fortalecimento do ativismo judicial.

Por fim, faz-se uma reflexão sobre a questão da leitura acerca da decisão do STF sob o viés de postura condizente com o Estado de Exceção.

\section{A PRESUNÇÃO DE INOCÊNCIA COMO GARANTIA FUNDAMENTAL INDIVIDUAL}

Antes de fazer uma análise acerca dos dispositivos constitucionais, legais e 
jurisprudenciais relacionados ao princípio da presunção de inocência, ou princípio da não culpabilidade, cabe destacar que tal princípio é uma conquista da humanidade ${ }^{14}$ nas democracias ocidentais como forma de superação da irracionalidade punitiva e de busca de preservação de contra-poder do indivíduo face o Estado, sendo elevada a categoria de direito fundamental na maioria das constituições.

Para Michel Foucault (2012, p. 13) até o fim do século XVIII, a manifestação do poder de punir, "o suplício", era por excelência a forma de ritual público de visibilidade de dominação do monarca, a qual prevaleceu durante toda a Idade Média. O medo, portanto, seria a forma mais importante de manter a relação entre soberano e súdito, pela tradicional “dominação pelo terror”. O suplício era um ritual de confirmação da força soberana nessa perspectiva.

As manifestações contra o suplício e a humanização das penas se fortaleceram com o advento da chamada modernidade, o que motivou uma nova forma de punir, evitando o confronto direto entre o soberano e o súdito. A perspectiva seria de a justiça criminal punir em vez de vingar (FOUCAULT, 2012, p. 72). Os reformadores então propuseram a regra da verdade comum no qual em todo julgamento deveria ser comprovada de forma inquestionável a culpa de um acusado através de um processo com contraditório e ampla defesa. Um processo longo com avanço e retrocessos.

Como consequências das experiências anteriores de barbáries, começa a prevalecer a perspectiva de impedir que agentes estatais tratatassem como se culpado fosse qualquer pessoa que não houvesse sido condenada por sentença irrecorrível ante a possibilidade de erros e falhas humanas, uma vez que "não é a absolvição do culpado que afeta os fundamentos jurídicos, desacredita a Justiça, alarma a sociedade, ameaça os indivíduos, sensibiliza a solidariedade humana, mas a condenação do inocente que o afeta.” (LYRA, 1969, p. 12)

Apesar de ser uma norma processual penal, a mesma encontra-se prevista Constituição Federal de 1988 (CF/88) como garantia fundamental: “Art. 5, LVII: ninguém será considerado culpado até o trânsito em julgado de sentença penal condenatória" (BRASIL, 1988, On line $)^{1516}$.

14 Na Declaração dos Direitos do Homem e do Cidadão de 1789 consta em seu artigo $9^{\circ}$ : Todo acusado é considerado inocente até ser declarado culpado e, se julgar indispensável prendê-lo, todo o rigor desnecessário à guarda da sua pessoa deverá ser severamente reprimido pela lei." Disponível em <http://www.direitoshumanos.usp.br/index.php/Documentos-anteriores-\%C3\%A0-cria\%C3\%A7\%C3\%A3o-daSociedade-das-Na\%C3\%A7\%C3\%B5es-at\%C3\%A9-1919/declaracao-de-direitos-do-homem-e-do-cidadao1789.html> Acesso em 13. dez. 2016.

15 Como consequência dessa presunção de não tratamento do réu como culpado, tem-se a garantia do art. $5^{\circ}$, LXI da CF/88: LXI - ninguém será preso senão em flagrante delito ou por ordem escrita e fundamentada de 
Manifestando-se sobre a impossibilidade de entendimento diverso do que ficou estabelecido pelo poder constituinte originário, o Supremo Tribunal Federal no julgamento do Habeas Corpus 79.812/SP assim se manifestou:

o princípio constitucional da não culpabilidade em nosso sistema jurídico consagra uma regra de tratamento que impede que o Poder Público de agir e de se comportar, em relação ao suspeito, ao indiciado, ao denunciado ou ao réu, como se estes já houvessem sido condenados definitivamente por sentença do Poder Judiciário. (BRASIL, 2000)

Mesmo muitos juristas não acatando o tratamento da interpretação literal do texto constitucional que estabelece a não culpabilidade no artigo $5^{\mathrm{a}}$, LVII, da CF/88, no ano de 2009, portanto há 7 anos da data das decisões objeto do presente estudo, o STF solidificou entendimento (Habeas Corpus 84.078-7 - MG) da impossibilidade da chamada "execução penal provisória":

EMENTA: HABEAS CORPUS. INCONSTITUCIONALIDADE DA CHAMADA "EXECUÇÃO ANTECIPADA DA PENA". ART. 5, LVI I, DA CONSTITUIÇÃO DO BRASIL. DIGNIDADE DA PESSOA HUMANA. ART. $1^{\circ}$, III, DA CONSTITUIÇÃO DO BRASIL.

(...)

3. A prisão antes do trânsito em julgado da condenação somente pode ser decretada a título cautelar.

4. A ampla defesa, não se a pode visualizar de modo restrito. Engloba todas as fases processuais, inclusive as recursais de natureza extraordinária. Por isso a execução da sentença após o julgamento do recurso de apelação significa, também, restrição do direito de defesa, caracterizando desequilíbrio entre a pretensão esta tal de aplicar a pena e o direito, do acusado, de elidir essa pretensão. (BRASIL, 2009, On line)

Como se pode constatar no "item 3." da decisão, o princípio da presunção de inocência não impede que ocorra prisões cautelares (prisão temporária ou prisão preventiva), devidamente fundamentadas de acordo com o Código de Processo Penal (CPP) ${ }^{17}$ :

Art. 283. Ninguém poderá ser preso senão em flagrante delito ou por ordem escrita e fundamentada da autoridade judiciária competente, em decorrência de sentença

autoridade judiciária competente, salvo nos casos de transgressão militar ou crime propriamente militar, definidos em lei; (BRASIL, 1988, On line)

16 Outro direito fundamental individual é a duração razoável do processo previsto no art. $5^{\circ}$, LXXVIII, da CF/88:a todos, no âmbito judicial e administrativo, são assegurados a razoável duração do processo e os meios que garantam a celeridade de sua tramitação, pois o julgamento rápido, respeitando o devido processo legal, também é de interesse do acusado para, por exemplo, não se prejudicar com a demora do julgamento que porventura seja inocentado.

17 Ressalta-se que no Código de Processo Penal, um Decreto-Lei que foi outorgado por Getúlio Vargas durante o Estado Novo, quase sempre prevaleceu uma perspectiva inquisitória, alterando-se um pouco essa realidade prática com o advento da Constituição Federal de 1988. "O Código de Processo Penal Italiano de 1930 foi a matriz ideológica que ensejou a produção científica do Código de Processo Penal brasileiro de 1941 (Lei n. 3.689) e sua raiz enfática é exatamente o sistema inquisitório, modelo teórico identificado pela prevalência de um processo eminentemente repressivo e autoritário, avesso Às garantias do acusado / investigado." (CABRERA, 2016, On line). 
condenatória transitada em julgado ou, no curso da investigação ou do processo, em virtude de prisão temporária ou prisão preventiva. (Redação dada pela Lei no 12.403 , de 2011).

$\S 1$ o As medidas cautelares previstas neste Título não se aplicam à infração a que não for isolada, cumulativa ou alternativamente cominada pena privativa de liberdade. (Incluído pela Lei $\mathrm{n}^{\circ} 12.403$, de 2011).

$\S 20$ A prisão poderá ser efetuada em qualquer dia e a qualquer hora, respeitadas as restrições relativas à inviolabilidade do domicílio. (Incluído pela Lei $\mathrm{n}^{\mathrm{o}}$ 12.403, de 2011). (BRASIL, 1941, On line)

Atente-se que, consoante expressa disposição da Constituição, em relação ao aspecto jurídico, a questão estava consolidada até as decisões recentes que passaram a possibilitar a execução provisória de pena na hipótese de haver condenação em $2^{\circ} \mathrm{Grau}$, mesmo que haja recurso para os Tribunais Superiores.

Defende-se no presente estudo, que a referida situação passa ter novo entendimento fruto do contexto político que o país passou a viver após junho de 2013. Tema a ser explorado no próximo tópico.

\section{O CONTEXTO POLÍTICO NACIONAL APÓS JUNHO DE 2013: CRESCIMENTO DO MORALISMO E ATIVISMO JUDICIAL}

Cabe destacar que, apesar de ser alto o índice de crimes praticados no Brasil na atualidade $^{18}$ a violência é uma marca da realidade histórica do país desde a invasão de terras indígenas, a escravidão negra, o cangaço e a repressão policial nas periferias das grandes cidades. Historicamente a prisão tem sido a única política do Estado utilizada para tentar diminuir estatísticas relativas ao aumento da violência, mas estas só crescem.

Não existe uma teoria geral dos motivos para a prática de crimes em geral, pois o crime de roubo cometido por pessoas tendo em vista a manutenção de vício é diferente do homicídio que ocorre por motivação de traição da vítima companheira ou da sonegação físcal por um grande empresário. Todos são vistos como apenas como crime, porém cada um tem suas peculiaridades e motivações distintas.

Várias são as correntes que procuram explicar as razões para a prática de crimes. As teorias enfatizam o indivíduo, sob os aspectos biológicos (como a superada frenologia) ou

18 Segundo o IPEA (Instituto de Pesquisa Econômica Aplicada), o Brasil atingiu 57.627 mortes violentas em 2014, um aumento de 21,9\% do número de homicídios comparado com o ano de 2003. O número de mortes violentas no Brasil representavam $10 \%$ do total mundial, ocupando o país a liderança de óbitos em números absolutos,

Pesquisa disponível <http://infogbucket.s3.amazonaws.com/arquivos/2016/03/22/atlas_da_violencia_2016.pdf>, acesso em 13. dez. 2016. 
psicológicos, outras com ênfase na sociedade, seja na pobreza, na desigualdade de renda, teoria do controle e cultura. Porém o discurso de combater a criminalidade apenas pela repressão é o que prevalece na sociedade, em especial nas campanhas sensacionalistas da mídia, sem que se faça um estudo sério sobre as origens dos crimes no Brasil.

Porém, o maior dilema do "punitivismo" é o ataque a direitos fundamentais e, em tempo de crises econômica e política, os mesmos ficam mais vulneráveis, já que a democracia é testada nesses momentos.

A economia nacional, que teve grande resultados desde os fins dos anos 90 até o ano de $2012^{19}$, com expansão do consumo e de políticas sociais, em razão dos autos preços das commodities (dentre os quais o petróleo), começou a sofrer as consequências do desaceleramento da economia chinesa, que, somando algumas decisões equivocadas de governo federal (AGÊNCIA BRASIL, 2016, On line), prejudicaram em muito a estabilidade política do país. A crise que em 2008 atingiu o centro do capitalismo mundial definitivamente chegou à periferia.

Tal crise econômica repercutiu de forma direta no campo político, que somando à deflagração da "Operação Lava Jato", a qual proporcionou investigações, acusações e condenações graves de corrupção a membros do poder público, mas precisamente lavagem de dinheiro na empresa estatal Petrobrás, mudaria os rumos do país. O Brasil, em Junho de 2013, também se preparava para receber o evento de campeonato de futebol Copa das Confederações da Fifa, quando a partir de manifestações populares por melhoria de transporte público na cidade de São Paulo ${ }^{20}$, setores mais conservadores da sociedade aproveitaram-se da situação de insatisfação geral com a política institucional, passaram a se manifestar publicamente pelo fim da democracia e volta à ditadura militar em razão do chamado "combate à corrupção".

Há de se ressaltar que mesmo ocorrendo acontecimentos graves ligados à corrupção anteriormente, como o julgamento da ação penal 470, até então não proporcionaram a mesma repercussão da crise política de 2013 em diante. O desgaste do poder do grupo político do governo federal pelo tempo foi um fator, mas a crise econômica foi preponderante.

Para Arantes (2016, Online), as manifestações de junho de 2013 são o marco do ressurgimento de manifestações de direta "não convencional", que não está contemplada pelos esquemas tradicionais da política. Isso porque, negando a política, muitos de seus

19 No ano de 2010, por exemplo, o PIB do País chegou a crescer 7,5\% ao ano, a maior marca desde 1986. (AGÊNCIA BRASIL, 2016, On line)

20 Estudantes ligados ao "Movimento Passe Livre" que tinham como bandeira central a tarifa zero para o transporte público. 
membros adotam a chamada "polarização assimétrica" por defender posições nítidas e inegociáveis, sem contemporizações. A negação da política e a polarização assimétrica inviabilizam a possibilidade de consenso por sobreposição razoável.

Em Theory of Justice, de Jown Rawls, defende-se que tal perspectiva se afasta da democracia, pois a sua tese é da busca do direito a partir do consenso, cabendo ao Estado aplicá-lo mediante "coerção revisável” pela cambiante opinião social (RAWLS, 1981, p. 4). O papel das garantias fundamentais são essenciais em tempo de crises, pois aí sim se manifesta o verdadeiro caráter democrático das instituições, já que para Rawls a ideia de consenso da política cotidiana não se confunde com a ideia de consenso limitada pela razão pública em $O$ liberalismo político.

Todo esse contexto, abre margem para radicalismos de pessoas da sociedade que possuem dificuldade de compreender a dificuldade da vida e das relações humanas, isto é, o caráter plural de existência (PRADO, 2016, On line), o que dá margem ao moralismo como discurso simplista de superação das mesmas, inclusive buscado se justificar o desrespeito a garantias fundamentais.

A "luta contra a corrupção" então passou a ser o instrumento para que o que deveria ser um tema para o debate público na busca de consensos sobre mais transparência na gestão pública, controle social de orçamento, democracia direta, etc, para ser alvo de perseguição a ideologias mais progressistas e ataques a direitos fundamentais a partir de uma conduta justificada por uma moral construída por inimigos políticos e a grande mídia, que contraditoriamente nada propõe nesse sentido.

Para Prado (2016, on line):

O fascismo infiltra-se na democracia, vale-se de extratos do discurso democrático para ampliar o leque de influência das ideias de homogeneidade do corpo social, que claro são convite a "expulsar" os diferentes desse "corpo" hipoteticamente salutar, maculado pelos que não professam as mesmas ideias.

Dessa maneira, o "enfrentamento à corrupção", tema relevante para o Brasil, acaba sendo um discurso que, da maneira que está sendo imposto, impossibilita consensos e avanços, além de desrespeitar essenciais constitucionais, inclusive por parte do Poder Judiciário e Ministério Público, instituições que devem ter um cuidado especial com os direitos fundamentais para de fato se viver uma democracia.

Para Streck (2016, On line), entretanto, tem-se tomado um caminho contrário. 
Atuando como seres eminentemente políticos, setores do Ministério Público Federal21, instituição que possui os mesmos vícios e virtudes das restantes da república, propuseram o projeto de lei chamado "10 medidas contra a corrupção"22 baseados em sua essência no senso comum, "o punitivismo", buscando fragilizar direitos que foram conquistados a duras penas em um país marcado por desrespeito aos direitos fundamentais de sua população.

O Direito no país vem seguindo esse rumo, e o perigo está no moralismo comum levar ao retrocesso, sob a falsa expectativa de solução da criminalidade por confronto normativo. A decisão do STF que possibilitou a execução provisória da pena está dentro desse contexto.

\section{AS DECISÕES DO STF NO HABEAS CORPUS N $\mathbf{N}^{\circ} 126.292$ E AÇÕES DECLARATÓRIAS DE CONSTITUCIONALIDADE N 43 E 44}

Em 17.02.2016, o STF no julgamento do Habeas Corpus nº 126.292 SP proferiu, com a composição plena, decisão no sentido que a pena imposta em segunda instância pode ser automaticamente cumprida, sem a necessidade de se decretar qualquer prisão de natureza cautelar. O habeas corpus foi impetrado em face de decisão do Superior Tribunal de Justiça (STJ) o qual indeferiu pedido de liminar em HC lá apresentado. A defesa buscava afastar mandado de prisão expedido pelo Tribunal de Justiça do Estado de São Paulo (TJ-SP) consoante entendimento consolidado na mais alta corte do país. O STF, como se demostrará a seguir tem por função precípua garantir os direitos e princípios da Constituição Federal, jamais optar por uma interpretação sem fundamentação jurídica para burlar a mesma, excepcionalizado aquilo que o constituinte não fez:

\footnotetext{
O relator do caso, ministro Teori Zavascki, ressaltou em seu voto que, até que seja prolatada a sentença penal, confirmada em segundo grau, deve-se presumir a inocência do réu. Mas, após esse momento, exaure-se o princípio da não culpabilidade, até porque os recursos cabíveis da decisão de segundo grau, ao STJ ou STF, não se prestam a discutir fatos e provas, mas apenas matéria de direito. (...) $\mathrm{O}$ relator votou pelo indeferimento do pleito, acompanhado pelos ministros Edson Fachin, Luís Roberto Barroso, Luiz Fux, Dias Toffoli, Cármen Lúcia e Gilmar Mendes. A ministra Rosa Weber e os ministros Marco Aurélio, Celso de Mello e Ricardo Lewandowski, presidente da Corte, ficaram vencidos. Eles votaram pela manutenção da jurisprudência do Tribunal que exige o trânsito em julgado para cumprimento de pena e concluíram pela concessão do habeas corpus.
}

21 Para Aragão (2016, On line): "na verdade o que está por trás disso é um projeto de poder para fortalecer uma corporação, porque só trata de desequilibrar mais ainda a relação da acusação e defesa no Brasil".

22 Uma das medidas sequer precisou ser aprovada pelo parlamento, pois o Poder Judiciário, agindo contra a Constituição, em medida que será mais aprofundada no próximo tópico, agiu com legislador e inovou tomando uma decisão que viola o princípio do não retrocesso em termos de direitos e garantias individuais, justamente a execução provisória da pena. 
(BRASIL, 2016a, On line)

À luz do controle de constitucionalidade no país, tal decisão foi concedida em controle difuso de constitucionalidade, no julgamento de um caso concreto portanto, o que, mesmo em um julgamento por 6 a 4 de votos dos ministros, não possuiu caráter de declarar constitucional a execução penal provisória no país. Segundo a decisão para o caso concreto, após segunda instância, a pena poderia ser automaticamente cumprida, o que será mais aprofundado posteriormente.

Em razão desse quadro de ativismo que proporcionou uma ruptura na ordem democrática no que tange à garantia do indivíduo face o Estado, em um contexto de espetaculização da "operação lava jato", de apelo punitivista, exacerbado pela mídia, com questionamento de parcialidade de magistrados agindo não como julgador, mas acusador, motivado por outros interesses que não apenas o jurídico ${ }^{23}$, o Partido Nacional Ecológico (PEN) e o Conselho Federal da Ordem dos Advogados do Brasil (OAB) ajuizaram Ações Declaratórias de Constitucionalidade (ADC's 43 e 44) para declarar que o artigo 283 do CPP era constitucional, o que implicaria a vinculação obrigatória de que apenas se poderia decretar a prisão antes do trânsito em julgado de algum acusado com fundamentos em prisão preventiva, o que inviabilizaria a possibilidade de declarar automática após condenação de segundo grau, encerrando qualquer controvérsia sobre o caráter vinculativo da decisão do habeas corpus anterior:

Art. 283. Ninguém poderá ser preso senão em flagrante delito ou por ordem escrita e fundamentada da autoridade judiciária competente, em decorrência de sentença condenatória transitada em julgado ou, no curso da investigação ou do processo, em virtude de prisão temporária ou prisão preventiva. (BRASIL, 1941, On line)

O plenário do STF, ao julgar improcedente as ADC's 43 e 44, desrespeitou não só o que foi estabelecido pelo legislador ordinário, mas a Constituição Federal, que em seu artigo $5^{\circ}$, incisos LXII e LXI, expressamente determina que ninguém será considerado culpado, e consequentemente poderá sofrer as consequências de uma condenação, até trânsito em julgado de sentença penal condenatória, bem como criar mais uma hipótese de prisão (automática, sem necessidade de motivação), excepcionalizado o que também o que diz a Constituição que só autoriza nas hipóteses de prisão em flagrante delito ou por ordem escrita e fundamentada

23 Em razão de decisões abusivas, não é sem motivo o debate sobre a responsabilidade de membros do Poder Judiciário e Ministério Público. Ressalta-se, por exemplo, a decisão proferida pelo Tribunal Regional Federal da $4^{a}$ Região, que arquivou representação contra magistrado que indevidamente divulgou gravação de interceptação telefônica de escutas de presidente da república, reconhecida na reclamação 23.457 pelo STF, fundamentado no argumento excepcionalista de que "a Operação Lava Jato" não precisa seguir regras comuns. 
de autoridade judiciária (prisão cautelar), salvo nos casos de transgressão militar.

Votaram pelo provimento da declaração das ADC's e foram vencidos os ministros Marco Aurélio (relator), Rosa Weber, Celso de Mello, Ricardo Lewandowski e Dias Toffolli (parcialmente), que em seus argumentos defenderam essencialmente que:

O caso começou a ser analisado pelo Plenário em $1^{\circ}$ de setembro, quando o relator das duas ações, ministro Marco Aurélio, votou no sentido da constitucionalidade do artigo 283, concedendo a cautelar pleiteada. Contudo, com a retomada do julgamento na sessão desta quarta-feira (5), prevaleceu o entendimento de que a norma não veda o início do cumprimento da pena após esgotadas as instâncias ordinárias. (...) A ministra Rosa Weber acompanhou o voto do relator, entendendo que o artigo 283 do CPP espelha o disposto nos incisos LVII e LXI do artigo $5^{\circ}$ da Constituição Federal, que tratam justamente dos direitos e garantias individuais. "Não posso me afastar da clareza do texto constitucional", afirmou. Para Rosa Weber, a Constituição Federal vincula claramente o princípio da não culpabilidade ou da presunção de inocência a uma condenação transitada em julgado. "Não vejo como se possa chegar a uma interpretação diversa", concluiu. (...) O ministro Ricardo Lewandowski ressaltou que o artigo $5^{\circ}$, inciso LVII da Constituição Federal é muito claro quando estabelece que a presunção de inocência permanece até trânsito em julgado. "Não vejo como fazer uma interpretação contrária a esse dispositivo tão taxativo", afirmou. Para ele, a presunção de inocência e a necessidade de motivação da decisão para enviar um cidadão à prisão são motivos suficientes para deferir a medida cautelar e declarar a constitucionalidade integral do artigo do 283 do CPP. Assim, ele acompanhou integralmente o relator, ministro Marco Aurélio. (...) Seu voto, que acompanhou o do relator, foi enfático ao defender a incompatibilidade da execução provisória da pena com o direito fundamental do réu de ser presumido inocente, garantido pela Constituição Federal e pela lei penal. $\underline{\text { Segundo o ministro, a presunção de inocência é conquista histórica dos cidadãos na }}$ luta contra a opressão do Estado e tem prevalecido ao longo da história nas sociedades civilizadas como valor fundamental e exigência básica de respeito à dignidade da pessoa humana. Para o decano do STF, a posição da maioria da Corte no sentido de rever sua jurisprudência fixada em 2009 "reflete preocupante inflexão hermenêutica de índole regressista no plano sensível dos direitos e garantias individuais, retardando o avanço de uma agenda judiciária concretizadora das liberdades fundamentais". "Que se reforme o sistema processual, que se confira mais racionalidade ao modelo recursal, mas sem golpear um dos direitos fundamentais a que fazem jus os cidadãos de uma república", afirmou. (BRASIL, 2016b, On line) Sem grifo no original

Há de se ressaltar o voto que parcialmente foi vencido do Ministro Dias Toffoli:

O ministro acompanhou parcialmente o voto do relator, acolhendo sua posição subsidiária, no sentido de que a execução da pena fica suspensa com a pendência de recurso especial ao STJ, mas não de recurso extraordinário ao STF. Para fundamentar sua posição, sustentou que a instituição do requisito de repercussão geral dificultou a admissão do recurso extraordinário em matéria penal, que tende a tratar de tema de natureza individual e não de natureza geral - ao contrário do recurso especial, que abrange situações mais comuns de conflito de entendimento entre tribunais. Segundo Toffoli, a Constituição Federal exige que haja a certeza da culpa para fim de aplicação da pena, e não só sua probabilidade, e qualquer abuso do poder de recorrer pode ser coibido pelos tribunais superiores. Para isso, cita entendimento adotado pelo STF que admite a baixa imediata dos autos independentemente da publicação do julgado, a fim de evitar a prescrição ou obstar tentativa de protelar o trânsito em julgado e a execução da pena (BRASIL, 2016b, On line). Sem grifo no original 
Porém, em atitude típica de ativismo judicial24, uma interpretação de "Estado de Exceção" por violar expressamente normas constitucionais e ordinárias, venceu o voto de divergência do Ministro Edson Fachin, o qual foi acompanhado pelos ministros Roberto Barroso, Teori Zavaschi, Luis Fux, Gimar Mendes e Carmen Lúcia, que indeferiu os pedidos de declaração de constitucionalidade ações ajuizadas pela OAB e PEN.

Seus argumentos, que apenas demonstram o desrespeito ao papel do Poder Judiciário de promover a defesa de garantias e direitos fundamentais, foram os seguintes essencialmente:

Primeiro a votar na sessão de hoje, o ministro Edson Fachin abriu divergência em relação ao relator e votou pelo indeferimento da medida cautelar, dando ao artigo 283 do CPP interpretação conforme a Constituição que afaste aquela segundo a qual a norma impediria o início da execução da pena quando esgotadas as instâncias ordinárias. Ele defendeu que o início da execução criminal é coerente com a Constituição Federal quando houver condenação confirmada em segundo grau, salvo quando for conferido efeito suspensivo a eventual recurso a cortes superiores. Fachin destacou que a Constituição não tem a finalidade de outorgar uma terceira ou quarta chance para a revisão de uma decisão com a qual o réu não se conforma e considera injusta. Para ele, o acesso individual às instâncias extraordinárias visa a propiciar ao STF e ao Superior Tribunal de Justiça (STJ) exercer seus papéis de uniformizadores da interpretação das normas constitucionais e do direito infraconstitucional. (...) Seguindo a divergência, o ministro (Roberto Barroso) defendeu a legitimidade da execução provisória após decisão de segundo grau e antes do trânsito em julgado para garantir a efetividade do direito penal e dos bens jurídicos por ele tutelados. No seu entendimento, a presunção de inocência é princípio, e não regra, e pode, nessa condição, ser ponderada com outros princípios e valores constitucionais que têm a mesma estatura. (...) Barroso contextualizou a discussão citando exemplos para demonstrar que o entendimento anterior do STF sobre a matéria não era garantista, "mas grosseiramente injusto", e produziu consequências "extremamente negativas e constatáveis a olho nu". Entre elas, incentivou à interposição sucessiva de recursos para postergar o trânsito em julgado, acentuou a seletividade do sistema penal e agravou o descrédito da sociedade em relação ao sistema de justiça - o que, a seu ver, contribui para aumentar a criminalidade. (...)Ao acompanhar a divergência, o ministro Teori Zavascki reafirmou entendimento já manifestado no julgamento do HC 126292, de sua relatoria, afirmando que o princípio da presunção da inocência não impede o cumprimento da pena. Teori ressaltou que esta era a jurisprudência do Supremo até 2009. "A dignidade defensiva dos acusados deve ser calibrada, em termos de processo, a partir das expectativas mínimas de justiça depositadas no sistema criminal do país", afirmou. Se de um lado a presunção da inocência e as demais garantias devem proporcionar meios para que o acusado possa exercer seu direito de defesa, de outro elas não podem esvaziar o sentido público de justiça. "O processo penal deve ser minimamente capaz de garantir a sua finalidade última de pacificação social", afirmou. Outro argumento citado pelo ministro foi o de que o julgamento da apelação encerra o exame de fatos e provas. "É ali que se concretiza, em seu sentido genuíno, o duplo grau de jurisdição", ressaltou. O ministro(Luiz Fux) seguiu a divergência, observando que tanto o STJ como o STF admitem a possibilidade de suspensão de ofício, em habeas corpus, de condenações em situações excepcionais, havendo, assim, forma de controle sobre as condenações em segunda instância que

24 "O ativismo é uma forma virulenta de pragmatismo jurídico. Um juiz ativista ignoraria o texto da Constituição, a história de sua promulgação, as decisões anteriores da Suprema Corte que buscaram interpretá-la e as duradouras tradições de nossa cultura política. O ativista ignoraria tudo isso para impor a outros poderes do Estado seu próprio ponto de vista sobre o que a justiça exige. O direito como integridade condena o ativismo e qualquer prática de jurisdição constitucional que lhe esteja próxima”. (DWORKIN, 1999, P. 451) 
contrariem a lei ou a Constituição. Segundo seu entendimento, o constituinte não teve intenção de impedir a prisão após a condenação em segundo grau na redação do inciso LVII do artigo $5^{\circ}$ da Constituição. "Se o quisesse, o teria feito no inciso LXI, que trata das hipóteses de prisão", afirmou. O ministro ressaltou ainda a necessidade de se dar efetividade à Justiça. "Estamos tão preocupados com o direito fundamental do acusado que nos esquecemos do direito fundamental da sociedade, que tem a prerrogativa de ver aplicada sua ordem penal", concluiu. (...) Gilmar Mendes votou com a divergência, avaliando que a execução da pena com decisão de segundo grau não deve ser considerada como violadora do princípio da presunção de inocência. Ele ressaltou que, no caso de se constatar abuso na decisão condenatória, os tribunais disporão de meios para sustar a execução antecipada, e a defesa dispõe de instrumentos como o habeas corpus e o recurso extraordinário com pedido de efeito suspensivo. Ele ressaltou que o sistema estabelece um progressivo enfraquecimento da ideia da presunção de inocência com o prosseguimento do processo criminal. "Há diferença entre investigado, denunciado, condenado e condenado em segundo grau", afirmou. Segundo Gilmar Mendes, países extremamente rígidos e respeitosos com os direitos fundamentais aceitam a ideia da prisão com decisão de segundo grau.(...)A presidente do STF (Ministra Cármen Lúcia) negou o pedido de cautelar nos pedidos. Ela relembrou, em seu voto, posicionamento proferido em 2010 sobre o mesmo tema quando acentuou que, quando a Constituição Federal estabelece que ninguém pode ser considerado culpado até o trânsito em julgado, não exclui a possibilidade de ter início a execução da pena - posição na linha de outros julgados do STF. Para a presidente, uma vez havendo apreciação de provas e duas condenações, a prisão do condenado não tem aparência de arbítrio. Se de um lado há a presunção de inocência, do outro há a necessidade de preservação do sistema e de sua confiabilidade, que é a base das instituições democráticas. "A comunidade quer uma resposta, e quer obtê-la com uma duração razoável do processo". Sem grifo no original.

Após todos os fundamentos dos ministros em desrespeitar o que determina a Constituição e o Código de Processo Penal, fica demonstrado na decisão da presidenta do STF25 de que "A comunidade quer uma resposta, e quer obtê-la com uma duração razoável do processo", um argumento eminentemente pessoal e fora do papel de guardião da constituição.

Inicialmente, como bem destacado pelo Ministro Celso de Mello, o fato de a legislação processual possibilitar demora no julgamento dos processos (na realidade falta uma autocrítica de promover celeridade pelos próprios juízes, presidentes que são dos processos criminais), não pode violar uma garantia fundamental. Tal mentalidade destrói todo um processo de construção de garantias e legitima a falta de investimento no Sistema de Justiça de forma eficiente, como, por exemplo, a polícia investigativa26.

O STF, portanto, está também inserido em Estado de Exceção ao descumprir a norma constitucional o que não é permitido: inovar no ordenamento jurídico, como se fosse Poder Constituinte Reformador, e mesmo este não pode fazê-lo como atuou politicamente o STF

25 Inclusive, atuando fora do papel que é de julgador, a Ministra Cármen Lúcia chegou a se reunir com as forças armadas para discutir um plano emergencial para a área de segurança pública, o que não é sua atribuição. (SERRANO, 2016, On line)

26 De 5 a $8 \%$ dos homicídios são elucidados no Brasil (GOMES, 2012, On line) por falhas na investigação em não se identificar indícios de autoria por falta de estrutura. 
nessa decisão em razão do princípio da vedação do retrocesso em direitos fundamentais individuais27. Segundo Lenio Streck "A maioria de seis votos fez política jurídica. Não fez Direito. O STF agiu como poder constituinte. Foram pronunciamentos morais sobre como deve ser o direito penal. Mas isso não compete ao STF”28

Isso porque tecnicamente como se pode sustentar que a presunção de culpa é afastada com uma condenação provisória em segunda instância, pendente de recurso, uma vez que a Constituição não determinou isso, apenas com trânsito em julgado. Não há "brecha" para a execução penal provisória automática, pois, mesmo encerrado a colheita de provas, possíveis recursos debatem matéria de direito que podem atingir o mérito29, logo de onde se concluir que se está permitido tal execução se não para o apelo do ativismo judicial de exceção, em que o Poder Judiciário em vez de respeitar as garantias inova no sentido de descumpri-las.

\begin{abstract}
Também se respaldou no Direito Comparado, para afirmar que não há "país nenhum do mundo, depois de observado o duplo grau de jurisdição, a execução de uma condenação fica suspensa aguardando referendo da Suprema Corte". Esqueceu (?), porém, de dizer que as Constituições dos Países cujas legislações foram consultadas não tratam os recursos constitucionais como a nossa, aliás, a maioria delas sequer trata de recursos. Nesta questão, a Constituição da República Federativa do Brasil é diferente. Ponto. Se não serve, muda-se, como propôs o Ministro César Peluso, ao defender a Proposta de Emenda à Constituição 15/2011 que estabelecia os recursos constitucionais como verdadeiras ações rescisórias. Mas quem pode fazê-lo não é o Supremo Tribunal Federal, pois não detém legitimidade (jurídica, popular) para tanto. No máximo, pode interpretá-la. E interpretar não é rascunhá-la, aditá-la, borrála, delir frases e construir outras em seu lugar em sentido absurdo e inadmissível. (MOREIRA \& ROCHA, 2016, On line)
\end{abstract}

Por fim, resta com preder como essa medida de excepcionalidade está inserida dentro das concepções de Estado de Exceção a fim de possibilitar reflexões sobre as mesmas.

\title{
5 O "ESTADO DE EXCEÇÃO” E SUA CORRELAÇÃO COM A EXECUÇÃO PROVISÓRIA DE PENA NO BRASIL
}

Cientes da dificuldade da definição do termo "estado de exceção" por situar-se no limite entre a política e o poder (AGAMBEN, 2004, P. 11), que está longe de ser um conceito

27 Canotilho (1998, p.321) explica à proibição de retrocesso: "inconstitucionais quaisquer medidas estaduais que, sem a criação de outros esquemas alternativos ou compensatórios, se traduzam na prática numa 'anulação', 'revogação' ou 'aniquilação' pura e simples desse núcleo essencial'.

28 Disponível em < http://www.conjur.com.br/2016-out-06/moro-aplaude-lenio-lamenta-veja-repercussaodecisao-stf> Acesso em 13. dez. 2016.

29 Exemplo seria a aplicação do princípio da insignificância. Como o tema será aprofundando no últmo tópico sobre Estado de Exceção e seu alcance, far-se-á uma abordagem mais significativa sobre o sujeito atingido segundo as concepções do mesmo. 
determinado e fechado, faz-se necessário o aprofundamento das decisões tomadas pelo STF à luz de seus pensadores.

A perspectiva de atenuação ou relativização de direitos e garantias individuais fundamentais, não ao ponto de esvaziá-lo ${ }^{30}$, não é algo estranho ao pensamento do constitucionalismo em situações de crises, que possam colocar em ameaça a soberania do Estado, que se qualificando como de Direito, deve adotar procedimento determinado anteriormente cuja doutrina reconhece como titular o povo, sempre de forma temporária ${ }^{31}$.

É um regímen extraordinário, mas não discricionário, um regímen de exceção, mas de exceção circunscrita pelo direito constitucional, submetida à vigilância das autoridades constitucionais, obrigada a uma liquidação constitucional de responsabilidades. É uma situação de arbítrio, mas arbítrio parcial, relativo, encerrado nas fronteiras de uma legalidade clara, imperativa, terminante, e em coexistência com o qual se mantêm os códigos, os tribunais, o corpo legislativo (BARBOSA, 1991, P. 225).

Dentro desse paradigma, as decisões estudadas, como devidamente comprovadas, não estão dentro de uma margem de autorização constitucional de relativização ${ }^{32}$, uma vez que a

30 No presente estudo, o questionamento que deve ser feito é qual o sentido que deve ser dado à garantia fundamental "ninguém será considerado culpado até trânsito em julgado de sentença penal condenatória," se o Estado pode automaticamente impor uma medida restritiva de liberdade antes de sua decisão final?! Nada sobra de eficácia da semântica desta norma fundamental.

$31 \mathrm{Na}$ ordem jurídica atual do Brasil, existem as instituições do Estado de Defesa e Estado de Sítio, previstas e regulamentados expressamente no texto constitucional de 1988 em seus artigos 137 a 139, os quais possibilitam expressamente restrições aos direitos fundamentais individuais de liberdade de reunião, sigilo de correspondência, sigilo de comunicações telegráficas e telefônicas, busca e apreensão.

32 Art. 136. O Presidente da República pode, ouvidos o Conselho da República e o Conselho de Defesa Nacional, decretar estado de defesa para preservar ou prontamente restabelecer, em locais restritos e determinados, a ordem pública ou a paz social ameaçadas por grave e iminente instabilidade institucional ou atingidas por calamidades de grandes proporções na natureza. $\S 1^{\circ} \mathrm{O}$ decreto que instituir o estado de defesa determinará o tempo de sua duração, especificará as áreas a serem abrangidas e indicará, nos termos e limites da lei, as medidas coercitivas a vigorarem, dentre as seguintes: I - restrições aos direitos de: a) reunião, ainda que exercida no seio das associações; b) sigilo de correspondência; c) sigilo de comunicação telegráfica e telefônica; II - ocupação e uso temporário de bens e serviços públicos, na hipótese de calamidade pública, respondendo a União pelos danos e custos decorrentes. $\S 2^{\circ} \mathrm{O}$ tempo de duração do estado de defesa não será superior a trinta dias, podendo ser prorrogado uma vez, por igual período, se persistirem as razões que justificaram a sua decretação. (...) Art. 137. O Presidente da República pode, ouvidos o Conselho da República e o Conselho de Defesa Nacional, solicitar ao Congresso Nacional autorização para decretar o estado de sítio (...) Art. 138. O decreto do estado de sítio indicará sua duração, as normas necessárias a sua execução e as garantias constitucionais que ficarão suspensas, e, depois de publicado, o Presidente da República designará o executor das medidas específicas e as áreas abrangidas. $\S 1^{\circ}-\mathrm{O}$ estado de sítio, no caso do art. 137, I, não poderá ser decretado por mais de trinta dias, nem prorrogado, de cada vez, por prazo superior; no do inciso II, poderá ser decretado por todo o tempo que perdurar a guerra ou a agressão armada estrangeira. (...)Art. 139. Na vigência do estado de sítio decretado com fundamento no art. 137, I, só poderão ser tomadas contra as pessoas as seguintes medidas: I - obrigação de permanência em localidade determinada; II - detenção em edifício não destinado a acusados ou condenados por crimes comuns; III - restrições relativas à inviolabilidade da correspondência, ao sigilo das comunicações, à prestação de informações e à liberdade de imprensa, radiodifusão e televisão, na 
eficácia do $\mathrm{HC}$ e ADC's não possuem caráter temporário (prazo de 30 dias no artigo 136, §2 e $138, \S 1^{\circ}$ ), muito menos estão nas previsões de excepcionalidade dos artigos 136 e 137 da $\mathrm{CF} / 88$, o que afastaria a constitucionalidade de tais decisões.

Carl Schmitt, pensador anti-liberal foi um crítico de tal perspectiva, pois a soberania não pertenceria ao povo, mas sim àquele o qual possui "o poder de decidir sobre o estado de exceção" (2006, p. 9), mesmo que sua efetivação implique na suspensão de toda ordem jurídica ${ }^{33}$.

Para Schimitt, la visión liberal está equivocada e institucionalmente es incapaz de tomar la decisión, como lo demostró, en su opinión, la crisis de la república de Weimar (1919-1933), sólo el soberano, cuyo poder es anterior al estado de derecho (divino), puede decidir, desde afuera del cuerpo del derecho, la suspensión del estado de excepción. (PONTE, 2012, p. 03)

O autoritarismo do pensamento schimittiano guarda relação com a postura ativista do STF adotada no presente caso, que atuou, na prática, sob o pretexto de "a sociedade espera uma resposta" como poder constituinte em suas decisões e não como poder constituído, implantando exceção à Constituição com a execução provisória, crítica que vem se ampliado a todo o Poder Judiciário por outras motivações que não jurídica:

O STF assumiu, com o Poder Judiciário que o segue, a condição de soberano na realidade brasileira. Decidindo como e quando há exceção, e a não se vincular às suas próprias decisões, agindo na conformidade da ocasião, o STF traz para seu exame o que não lhe é permitido: o controle da política e da Constituição (MONT'ALVERNE, 2016, On line)

Para Walter Benjamin, membro da Escola de Frankfurt, fortemente influenciado pelo pensamento de Karl Marx e Bertold Brech, o qual viveu todo o crescimento dos movimentos autoritários como o fascismo e nazismo, bem como a desilusão com o liberalismo ante a crise de 1929, defende em sua oitava tese sobre o conceito de história que a "tradição dos oprimidos ensina que o estado de emergência em que se vive é a regra ${ }^{34}$ ". Seu pensamento também vai de encontro ao idealismo do liberalismo porque busca na realidade fática, criticar a idealização dos direitos fundamentais.

forma da lei; IV - suspensão da liberdade de reunião; V - busca e apreensão em domicílio; VI - intervenção nas empresas de serviços públicos; VII - requisição de bens. (...) (BRASIl, 1988, On Line)

33 "o estado de exceção é sempre algo diferente da anarquia e do caos e, no sentido jurídico, nele ainda existe uma ordem, mesmo não sendo uma ordem jurídica." (SCHMITT, apud AGAMBEN, 2004, p. 54).

34 A tradição dos oprimidos nos ensina que o "estado de exceção" em que vivemos é na verdade a regra geral. Precisamos construir um conceito de história que corresponda a essa verdade. Nesse momento, perceberemos que nossa tarefa é originar um verdadeiro estado de exceção; com isso, nossa posição ficará mais forte na luta contra o fascismo.(BENJAMIN, 1940, P. 03) 
Es la violencia sobre los oprimidos que define que su situación exprese el estado de excepción permanente. De esta manera, el soberano no tiene (como tampoco las autoridades del estado liberal) la capacidad de decidir sobre el estado de excepción, pues éste es la regla. (PONTE, 2012, p. 03)

Trazendo essa perspectiva para a possibilidade de execução penal provisória, apesar de Benjamin entender que estado de exceção não faz parte de um debate jurídico, mas da violência, em especial do Estado, não deixa de ser relevante a sua perspectiva realista.

Em termos de processo penal, muito se sabe que, no Brasil, o público cativo são tradicionalmente pessoas pobres no aspecto econômico. Dados comprovam que ao passo que a Defensoria Pública vem se fortalecendo no país, há uma grande margem de decisões de vulneráveis sendo reformadas em tribunais superiores.

Uma pesquisa realizada junto ao Superior Tribunal de Justiça e Supremo Tribunal Federal mostrou que em $41 \%$ dos recursos da Defensoria Pública do Rio de Janeiro e em 64\% dos recursos da Defensoria Pública de São Paulo foram reconhecidas alguma injustiça. Os números provam a importância desses instrumentos para que a Constituição e a lei sejam aplicadas corretamente. (RIO DE JANEIRO, 2016a, On line)

Considerando-se que apenas as Defensorias Públicas dos Estados do Rio de Janeiro e São Paulo possuem estrutura mínima adequada para recorrer e acompanhar devidamente processos de réus condenados após segunda instância nos tribunais superiores, e que, conforme as estatísticas, de uma forma ou outra possuíram algum direito desrespeitado em decisão de segunda instância, não é difícil concluir que o direito à plena defesa (com o direito de utilizar todos os recursos cabíveis com respeito à presunção de inocência sem execução penal provisório) é violado para a maior parte das pessoas, devido à falta de estrutura da Defensoria Pública no país ${ }^{35}$.

É fato notório que a maioria dos acusados em um processo penal não podem contratar um advogado para recorrer até as últimas instâncias superiores, que é bastante caro. O Estado de exceção na concepção de Walter Benjamin no aspecto acesso à justiça já é uma realidade para grande parte dos acusados, antes mesmo das decisões do STF que possibilitou execução provisória, portanto fora de qualquer aspecto normativo.

Em pesquisa promovida pelo Instituto de Pesquisa Econômica Aplicada (IPEA) para o Ministério da Justiça e realizada pela Escola de Direito do Rio de Janeiro da Fundação Getúlio Vargas, foi constatada uma alta taxa de reversão das decisões dos tribunais de segunda instância em sede de habeas corpus no STJ e STF entre 20082012. Ainda maior é o índice de alteração das decisões quando analisados os

35 decreta a anomia e funda o modelo jurídico político do ocidente. Uma zona de penumbra na qual a suspensão da validade do ordenamento se confunde com a vigência do ordenamento, sem representar, propriamente, uma exclusão daqueles que não estão contemplados por ele. (PEREIRA, 2011, P. 66) 
recursos especiais. No STJ, entre 2014 e 2015, 58,40\% dos recursos especiais do Ministério Público foram julgados procedentes, contra um percentual de $14,18 \%$ de improcedência. Quando analisados os recursos da defesa, a taxa de sucesso foi igualmente relevante, tendo havido acolhimento do pedido em 45,99\% dos casos, contra $15,16 \%$ de recursos julgados improcedentes. Em matéria penal, no período de 2014-2015, a maior parte das decisões do STJ foi de procedência $(54,42 \%)$, alterando o julgamento do tribunal de segunda instância. (RIO DE JANEIRO, 2016b, 16).

Mesmo utilizando-se de um argumento utilitarista, as estatísticas demonstram que em mais da metade de todos os casos penais de atuação da Defensoria de São Paulo e Rio de Janeiro, teria ocorrido desnecessidade de manter acusados presos. Caso contrário, após a mudança de entendimento do STF, haveria mais um erro judicial irreparável.

Giogio Agaben, professor italiano responsável pela tradução da obra de Walter Banjamin, define o "estado de exceção" da seguinte forma: "não é um direito especial (como o direito de guerra), mas, enquanto suspensão da própria ordem jurídica, define seu patamar ou seu conceito de limite.” (2004, p. 15).

Após fazer uma abordagem sobre o instituto do direito romano "Iustitium" que significa, suspensão do direito (2004, p. 68), o mesmo afirma categoricamente que não se pode confundir estado de exceção com ditadura (constitucional ou inconstitucional, comissionária ou soberana), mas um espaço vazio de direito, uma zona de anomia, em que todas as determinações jurídicas - e, antes de tudo, a própria distinção ente públicos e privados - estão desativados.” (2004, p. 78).

Essa perspectiva é a que mais se aproxima da realidade que se vive com a atual situação de excepcionalidade de decisões ativistas pelo STF que violam a democracia, porém sem se caracterizar uma autêntica ditadura (que se caracteriza por uma excepcionalidade geral de desrespeito manifestadamente contrário à constituição), o que provoca preocupações com a possibilidade plena de continuidade de medidas excepcionais a um ponto de virar regra.

\footnotetext{
A suspensão do ordenamento vigente, para a garantia de sua sobrevivência, acentua Agamben, não suscita uma resposta a uma lacuna normativa; o estado de exceção apresenta-se como a abertura de uma lacuna fictícia no ordenamento, com o objetivo de salvaguardar a existência da norma e sua aplicabilidade à situação normal. (AGAMBEM, 2004, p. 15).
}

Dessa forma, apesar de uma suposta matriz democrática, o estado de exceção caminha com o totalitarismo, em ascendência no Brasil após junho de 2013, contando com apoio de parcela mais conservadora da sociedade, anulando gradativamente o estatuto jurídico do indivíduo, tudo suportado na generalização de paradigmas de segurança e de combate à corrução como técnica moral de governo através de apoio político dos meios de comunicação 
social.

\begin{abstract}
La excepción no tiene que ver con la suspensión del estado de derecho, del derecho constituido; tampoco dice respecto de la sentencia benjaminiana de la situación de los oprimidos, ni tampoco con la excepcionalidad del funcionamiento del orden burgués. El estado de excepción permanente se establece, además de lo señalado por Benjamín y por De Oliveira, por la ambigüedad en la aplicación de la norma jurídica. Por el hecho de que tanto las autoridades como los ciudadanos en ocasiones la aplican o la observan y en otras la ignoran y utilizan otras normas no jurídicas para definir sus relaciones. No se trata pues de la suspensión del estado de derecho como un todo, no es el estado de sitio o la suspensión de las garantías, o el hecho de que para algunos sectores de la población el derecho y la justicia no existe; se trata de su aplicación ambigua, de su violación permanente. No se refiere tampoco a una situación de anomia o de caos, expresa un orden definido por medio del cual se reproduce la sociedad (PONTE, 2012, p. 10).
\end{abstract}

Desta forma, essa tendência cada vez mais repercutindo no Direito Penal, não só prejudica os mais pobres, mas toda a sociedade que pode ser vitimada, inclusive perseguidos políticos de uma possível justiça não parcial, que apesar de não ser pobre economicamente falando, retrocedendo para ser um instrumento que pode afetar a qualquer um.

\title{
6 CONSIDERAÇÕES FINAIS
}

O STF decidiu no julgamento do Habeas Corpus 126.292 e ADC's 43 e 44, por maioria de seus membros, a possibilidade de execução provisória de pena. Essa decisão viola diretamente o texto constitucional de forma clara. Inclusive promoveu um vazio semântico na norma prevista no art. $5^{\circ}$, LVII da $\mathrm{CF} / 88$, pois a mesma é taxativa ao mencionar que ninguém pode ser considerado culpado sem decisão transitada em julgado.

Com a possibilidade de se prender automaticamente alguém que após decisão de segunda instância sofre condenação provisória pendente de recurso, não há outra perspectiva do que trabalha com a ideia de que a presunção de culpa passa a ocorrer em tal situação. E se há presunção de culpa, há violação à Constituição. A prisão cautelar não se confunde com tal perspectiva.

Deve-se compreender essa possibilidade, que representa um regresso ao respeito às garantias fundamentais, a partir do ativismo judicial que o Poder Judiciário e, consequentemente, o STF tem utilizado nas suas decisões, em especial no controle de constitucionalidade.

Agindo muitas vezes não como um guardião da Constituição, tal protagonismo sem nenhum controle social, muitas vezes rompe com seu papel de poder constituído e motivado 
através do senso comum da mídia e do pensamento conservador que avançou após junho de 2013, provoca-se quebra de jurisprudência recente da própria corte, como foi o caso de mudar totalmente seu entendimento fixado no ano de 2009 sobre a matéria objeto desse trabalho.

Após abordar as decisões dos ministros, inclusive com os argumentos utilizados na tese vencedora, ficou demonstrado que a decisão atendeu um viés político e não jurídico, pois, nas próprias palavras da presidente da Corte, ficou demonstrado que a execução penal provisória era uma resposta à sociedade. Definitivamente, não é papel do Poder Judiciário, ou de qualquer outro poder da república, excepcionar aplicação de normas eficazes e válidas. No presente estudo, houve um retrocesso em reduzir o alcance do art. $5^{\circ}$, LVII da CF/88 sob um viés simplório punitivista.

\section{REFERÊNCIAS}

AGAMBEM, Giorgio. Estado de exceção. Tradução de Iraci D. Poleti. Boi Tempo: São Paulo, 2004.

AGÊNCIA BRASIL. Entenda a crise econômica. Brasília. Disponível em: $<$ http://agenciabrasil.ebc.com.br/economia/noticia/2016-05/entenda-crise-economica $>$. Acesso em: 11 dez. 2016.

ARANTES, Paulo Eduardo. Nova direita surgiu após junho, diz filósofo . Folha de São Paulo, Campos de Jordão, $31 \quad$ outubro 2014. Disponível em: $<$ http://www1.folha.uol.com.br/poder/2014/10/1541085-nova-direita-surgiu-apos-junhodiz-filosofo.shtml>. Acesso em: 11 dez. 2016.

BARBOSA, Rui. Obras completas de Rui Barbosa - trabalhos diversos. Rio de Janeiro: Secretaria da Cultura, 1991. vol. XL 1913. Tomo VI.

BENJAMIN, Walter. Teses sobre o conceito de história. 1940. Disponível em $<$ http://mariosantiago.net/Textos $\% 20 \mathrm{em} \% 20 \mathrm{PDF} /$ Teses $\% 20$ sobre $\% 20 \mathrm{o} \% 20$ conceito $\% 20 \mathrm{de} \%$ 20hist\%C3\%B3ria.pdf> Acesso em: 13 dez. 2016.

BRASIL. Constituição (1988). Constituição da República Federativa do Brasil. Brasília, DF, 1988. Disponível em: <http://www.planalto.gov.br/ccivil_03/constituicao/constituicao.htm>. Acesso em: 11 dez. 2016. 
BRASIL. Decreto Lei n ${ }^{o}$ 3.689, de 03 de outubro de 1941. Rio de Janeiro, RJ, 1941. Disponível em: <http://www.planalto.gov.br/ccivil_03/decreto-lei/Del3689.htm> Acesso em: 13 dez. 2015.

BRASIL. Supremo Tribunal Federal. Habeas Corpus 79812-8 - SP. Paciente: José Corissa Neto. Impetrante: Antônio Cândido Reis de Toledo Leite. Coautor: Comissão Parlamentar de Inquérito. Relator: Ministro Celso de Melo. Brasília, 8 de novembro de 2000. Disponível em: $<$ http://redir.stf.jus.br/paginadorpub/paginador.jsp? docTP $=A C \&$ docID $=78158>$. Acesso em: 13 dez. 2016.

BRASIL. Supremo Tribunal Federal. Habeas Corpus 84078-7 - SP. Paciente: Omar Coelho Vitor. Impetrante: Omar Coelho Vitor. Coautor: Superior Tribunal de Justiça. Relator: Ministro Eros Roberto Grau. Brasília, 5 de fevereiro de 2009. Disponível em: < http://www.stf.jus.br/arquivo/cms/noticiaNoticiaStf/anexo/ementa84078.pdf>. Acesso em: 13 dez. 2016.

BRASIL. Supremo Tribunal Federal. Pena pode ser cumprida após decisão de segunda instância, decide STF. Brasília, 17 de fevereiro de 2016. Disponível em: < http://www.stf.jus.br/portal/cms/verNoticiaDetalhe.asp?idConteudo=310153>. Acesso em: 13 dez. 2016.

BRASIL. Supremo Tribunal Federal. STF admite execução da pena após condenação em segunda instância. Brasília, 05 de outubro de 2016. Disponível em: < http://www.stf.jus.br/portal/cms/verNoticiaDetalhe.asp?idConteudo=326754 $>$. Acesso em: 13 dez. 2016.

CABRERA, Michelle Gironda. A mentalidade inquisitória no processo penal brasileiro. Canal Ciências Criminais. Disponível em: <https://canalcienciascriminais.com.br/mentalidadeinquisitoria/>. Acesso em: 13 dez. 2017.

CANOTILHO, José Joaquim Gomes. Direito Constitucional e Teoria da Constituição. 2. ed. Coimbra: Almedina, 1998.

DWORKIN, Ronald. O império do direito. Tradução Jefferson Luiz Camargo. São Paulo: Martins Fontes, 1999.

FOUCAULT, Michel. Vigiar e punir; história da violência nas prisões. Tradução de Raquel Ramalhete. 40ª Edição. Editora Vozes: Petrópolis -RJ, 2012.

LYRA, ROBERTO. Introdução ao Estudo do Direito Penal Adjetivo e do Direito Penal Executivo, Imprensa: Rio de Janeiro, Ed.do Autor, 1969. 
MONT'ALVERNE, Martônio. Estado de exceção e democracia. O Povo. Conjuntura. 04 dez. 2016.

$<$ http://mobile.opovo.com.br/app/opovo/opiniao/2016/10/04/noticiasjornalopiniao,3662208/es tado-de-excecao-e-democracia.shtml> Acesso em: 12. dez. 2016.

MOREIRA, Romulo de Andrade, ROCHA, Jorge Bheron. Supremo: de guardião a carcereiro da Constituição. Disponível em: <http://emporiododireito.com.br/supremo-de-guardiao-acarcereiro-da-constituicao-de-jorge-bheron-rocha-e-romulo-de-andrade-moreira/> Acesso em: 12 dez. 2016.

PEREIRA, Gustavo Oliveira de Lima. A pátria dos sem pátria. Direitos humanos e alteridade. Porto Alegre: Editora UniRitter, 2001.

PONTE, Víctor Manuel Durand. Estado de Excepción Permanente. Universidade Nacional Autônoma de México. Disponível em: $<$ http://conceptos.sociales.unam.mx/conceptos_final/491trabajo.pdf $>$ Acesso em: 12 dez. 2016.

PRADO, Geraldo. O fascismo avança. São Paulo. Disponível em: $<$ http://www.sasp.org.br/jornal-sasp/722-o-fascismo-avanca.html $>$. Acesso em: $12 \mathrm{dez}$. 2016 .

RAWLS, John. Uma teoria da justiça. Tradução de Vamireh Chacon. Brasília: Editora Universidade de Brasília, 1981.

RIO DE JANEIRO. Defensoria Pública do Estado do Rio de Janeiro. Relato 10 Medidas em xeque. Pelo fim da corrupção sem perda de direitos. Disponível em: $<$ http://10medidasemxeque.rj.def.br/campanha/>. Acesso em: 15 dez. 2016.

RIO DE JANEIRO. Defensoria Pública do Estado do Rio de Janeiro. 10 Medidas em xeque. Uma análise crítica das propostas de combate à corrupção. Pelo fim da corrupção sem perda de direitos. Disponível em: $<$ http://www.defensoria.rj.def.br/uploads/imagens/d8a82703a08b4a4096424c576bdff239.pdf $>$ . Acesso em: 14 dez. 2016.

SERRANO, Pedro Estevam. Ataques cotidianos à democracia e a escalada do Estado de exceção. 31 out. 2016.. Disponível em: <http://www.cartacapital.com.br/sociedade/ataquescotidianos-a-democracia-e-a-escalada-do-estado-de-excecao> Acesso em: 14 dez. 2016.

SCHMITT, apud AGAMBEN, Giorgio. Estado de Exceção. São Paulo: Boitempo, 2004. 
SCHMITT, Carl. Teologia Política. Tradução de Elisete Antoniuk. Belo Horizonte: Del Rey, 2006.

STRECK, Lenio Luiz. O pacote anticorrupção do Ministério Público e o fator Minority Report. Consultor Jurídico, 03 mar. 2016. Disponível em: <http://www.conjur.com.br/2016mar-03/senso-incomum-pacote-anticorrupcao-mpf-fator-minority-report $>$. Acesso em: $12 \mathrm{dez}$. 2016.

PROVISIONAL CRIMINAL EXECUTION AUTHORIZED BY STF: EXPANSION OF EXCEPTION STATE IN BRAZIL

\begin{abstract}
The purpose of this study is to analyze Habeas Corpus Supreme Court decisions 126,292 SP and Declaratory Constitutional Actions 43 and 44 , which provoked an intense legal debate, in light of the theory of the state of exception. These decisions allowed for the provisional execution of a sentence after second-degree conviction by the Judiciary, even pending appeal to a higher court, without the need to establish possible pre-trial detention, already provided for in the law. The question is whether such a decision does not expressly violate the presumption of innocence provided for in article 5, item LVII of the Federal Constitution of 1988. It seeks to verify whether the decision is related to the political and economic context that the country came to live after the demonstrations of June 2013. Next, a legal and doctrinal approach is taken to the decisions of the ministers on the abovementioned decisions. We analyze the thoughts of Carl Schimitt, Walter Benjamin and Giorgio Agambem on state of exception. An approach is made, bringing a parallel of the main ideas of these thinkers with the issue of automatic criminal detention after second-degree conviction. The research was carried out through a bibliographic study. This controversial decision changed the understanding pacified by the STF itself in 2009.
\end{abstract}

Keywords: State of exception. Presumption of innocence. Fundamental rights. 